\title{
StrategiC
}

\section{PENGEMBANGAN PROMOSI WISATA MUSEUM KOTA BANDUNG MELALUI MEDIA BILLBOARD DESAIN KARTUN DALAM MENINGKATKAN MINAT WISATAWAN}

\author{
Ani Solihat \\ ani.ani@bsi.ac.id \\ AMIK BSI Bandung \\ Maxsi Ary \\ Maxsi.max@bsi.ac.id \\ AMIK BSI Bandung
}

\begin{abstract}
ABSTRAK
Minat wisatawan belanja dan kuliner di Kota Bandung saat ini tidak signifikan dengan minat wisatawan museum Kota Bandung. Sejak tahun 2014 Kota Bandung banyak dilakukan pembenahan di berbagai tempat seperti, pembuatan taman tematik, pembenahan Alun-Alun, perbaikan jalan termasuk trotoar, pembuatan flyover dengan teknologi struktur baja bergelombang, termasuk wilayah Asia Afrika yang dijadikan sebagai tempat Konferensi Asia Afrika ke-50, hal ini salah satu magnet meningkatkan para wisatawan untuk mengunjungi Kota Bandung. Bertambahnya para wisatawan seharusnya merupakan potensi besar bagi pemerintah Kota Bandung dalam mempromosikan museum sebagai salah satu objek wisata yang patut untuk dikunjungi dan memperluas image Kota Bandung tidak hanya sebagai kota wisata belanja, wisata kuliner, tetapi juga sebagai wisata edukasi dan sejarah. Salah satu upaya mempromosikan museum di Kota Bandung melalui periklanan dengan menggunakan media billboard yang dipasang ditempat ramai dikunjungi oleh para wisatawan seperti di kawasan belanja, kuliner atau wista kota, sehingga dapat menambah referensi wisatawan dan dapat meningkatkan image Kota Bandung selain sebagai wisata belanja, wisata kuliner, juga sebagai wisata edukasi dan sejarah. Desain billboard sebagai cara mempromosikan harus benarbenar memiliki desaign dan isi pesan yang menarik serta jelas, singkat dan mudah dipahami dengan menempatkan pada tempat strategis yang banyak dilihat oleh para wisatawan. Hal ini merupakan salah satu cara mengkomunikasikan dan menginformasikan museum di Kota Bandung kepada para wisatawan sehingga dapat meningkatkan minat wisatawan mengunjungi museum di Kota Bandung. Metode penelitian yang digunakan adalah metode kuantitatif deskriptif verifikatif dengan menggunakan teknik analisis regresi sederhana, sedangkan responden pada penelitian ini adalah wisatawan Kota Bandung. Hasil penelitian menunjukan desain billboard yang dirancang sebagai media promosi wisata museum Kota Bandung dapat meningkatkan minat wisatawan.
\end{abstract}

\section{Kata kunci : Periklanan Media Billboard, Minat Pengunjung}

\section{PENDAHULUAN}

Sejak diangkatnya "Ridwan Kamil" sebagai Walikota Bandung pada tahun 2014 banyak dilakukan pembenahan di berbagai tempat seperti pembuatan taman tematik, pembenahan Alun-Alun, perbaikan jalan termasuk trotoar, pembuatan flyover dengan teknologi struktur baja bergelombang, termasuk wilayah Asia Afrika yang dijadikan sebagai tempat Konferensi Asia Afrika ke-50 dan berbagai tempat lainnya. Menurut Tazbir Abdullah (Asisten Deputi Bisnis dan Pemerintahan Kementerian Pariwisata RI) Kota Bandung dinilai menjadi salah satu kota dengan destinasi wisata yang menjadi andalan nasional (http://bandung.merdeka.com/). Banyaknya pariwisata di Kota Bandung menjadi pilihan bagi wisatawan nusantara maupun wisatawan mancanegara hal ini menjadi magnet para wisatawan untuk mengunjungi Kota Bandung. Namun ada beberapa tempat wisata yang belum diperhatikan oleh pemerintah Kota Bandung, salah satunya adalah wisata museum, padahal Kota Bandung selain dikenal dengan wisata fashion, wisata kuliner, wisata alam, juga wisata edukasi termasuk wisata museum. 


\section{StrategiC}

Dengan meningkatnya jumlah wisatawan Kota Bandung, hal ini seharusnya menjadi potensi besar pemerintah Kota Bandung dalam mempromosikan museum sebagai salah satu objek wisata yang patut untuk dikunjungi. Tahun 2016, Pemkot Bandung melalui Dinas Kebudayaan dan Pariwisata (Disbudpar) menargetkan 5,6 juta wisatawan Kota Bandung baik domestik maupun mancanegara, hal ini seharusnya menjadi peluang bagi wisata museum di Kota Bandung dalam mempromosikan pada wisatawan domestic maupun mancanegara. (http://regional.kompas.com).

Saat ini museum di Kota Bandung Kota Bandung memiliki 6 museum diantaranya Museum Geologi, Museum Konferensi Asia Afrika, Museum Mandala Wangsit Siliwangi, Museum Pos, Museum Negeri Sri Baduga, dan Museum Barli. Pengurus museum sampai sat ini melakukan promosi secara mandiri melalui pameran, padahal museum sebagai salah satu objek wisata edukasi yang dapat membentuk generasi lebih memahami sejarah dan menambah ilmu pengetahuan. Berdasarkan potensi wisatawan ke Kota Bandung yang cukup tinggi, sebaiknya pemerintah Kota Bandung memanfaatkannya dengan meningkatkan promosi melalui periklanan dengan menggunakan media billboard yang dipasang ditempat-tempat ramai dikunjungi para wisatawan seperti di kawasan belanja dan kuliner, sehingga dapat menambah referensi wisatawan untuk berwisata di Kota Bandung dan dapat menambah image Kota Bandung selain sebagai wisata belanja, wisata kuliner, juga sebagai wisata edukasi dan sejarah.

Iklan billboard di Kota Bandung saat ini belum dimanfaatkan untuk mempromosikan museum, seolah museum tidak memiliki potensi dan manfaat, padahal iklan menggunakan media billboard bermanfaat untuk meningkatkan kesadaran wisatawan akan keberadaan museum di Kota Bandung. Sebaiknya para pengelola museum dan pemerintah Kota Bandung bersama-sama berusaha meningkatkan minat wisatawan museum. Adapun penempatan iklan melalui media billboard haruslah benar-benar ditempatkan pada tempat strategis seperti di area wisata taman kota Alun-Alun Bandung atau Braga, di area Dago dan Cihampelas sebagai tempat wisata belanja, fashion dan kuliner, dan sebagainya. Sedangkan desain dan isi pesan billboard harus dirancang menarik, jelas, singkat, dan mudah dipahami. Dengan demikian desain yang telah dibuat semenarik mungkin bertujuan untuk meningkatkan minat wisatawan Kota Bandung.

\section{KAJIAN PUSTAKA}

Menurut Eka Wenats \& dkk (2012:5) menyampaikan bahwa promotion mix yang terdiri dari berbagai jenis alat komunikasi pemasaran (marketing tools) yaitu:

1. Iklan (advertising) merupakan kegiatan komunikasi pemasaran yang paling dikenal khalayak

2. promosi penjualan,

3. kehumasan,

4. penjualan personal,

5. pemasaran langsung, dan sebagainya

Beberapa alat promosi, atau dikenal dengan bauran promosi (promotion mix) terdiri atas variable, yaitu (Fredy Rangkuti, 2010:23):

1. Periklanan (advertising)

Periklanan adalah komunikasi non individu dengan sejumlah biaya, melalui berbagai media yang dilakukan oleh perusahaan, lembaga nirlaba serta individu.

Iklan telah dianggap sebagai manajemen citra yang bertujuan menciptakan dan memelihara cipta dan makna dalam benak konsumen dan tujuan akhir dalam iklan adalah bagaimana mempengaruhi perilaku pembelian konsumen.

Periklanan dapat disajikan dalam berbagai bentuk dan media sebagai berikut :

a. Media Cetak, terdiri dari:

a) surat kabar merupakan media periklanan yang paling efektif, dengan demikian media ini dimata masyarakat harus memiliki kesan yang positif karena media ini lebih banyak dibaca oleh masyarakat luas. Meskipun demikian, media ini juga mempunyai kelemahan karena pada umumnya surat kabar hanya dibaca satu kali dan kemudian dibuang sehingga kurang mendapat perhatian dari pembaca.

b) Majalah, media ini hampir sama dengan surat kabar, tetapi media ini hanya menerbitkan untuk orang-orang yang khususnya mempunyai rasa dan perhatian yang sama

c) brosur dan leaflet, merupakan selembaran yang dikirim atau diberikan ke berbagai perushaaan maupun perorangan yang dianggap sebagai pembeli potensial, sedangkan leaflet berisi informasi mengenai produk dan harga

d) direct mail adalah surat penawaran yang dikitimkan kepada pembeli potensial dan

Strategic, Volume 11, Nomor 20, Desember 2016 


\section{StrategiC}

mencantumkan fasilitas yang tersedia dengan penawaran dan harga khusus.

b. Media elektronik adalah media yang paling efektif dan banyak digunakan oleh perusahaan karena media ini dapat menjangkau lapisan masyarakat. Media elektronik terdiri dari :

a) media audio merupakan media yang hanya dapat didengar, dalam hal ini adalah radio dan telepon. Media audio lebih banyak digunakan adalah radio karena pengiklanan pada media ini biayanya relative murah. Disamping itu karena sifatnya audio maka tidak diperlukan keterampilan khusus untuk meyampaikan pesan yang disampaikan dalam media cetak yang memerlukan kecakapan untuk memahami pesan yang disampaikan

b) media audio visual merupakan media yang dapat dilihat dan didengar. media audio visual terdiri dari televisi, internet dan bioskop. Media ini cukup efektif karena dapat menimbulkan imajinasi tentang produk pada konsumen dan juga tidak harus memiliki keterampilan khusus dalam memahami pesan yang disampaikan.

c. Media outdoor (luar ruangan) terdiri dari:

a) Billboard merupakan iklan dipasang pada papan-papan besar bergambar yang dianggap strategis, mudah dilihat di jalan raya yang ramai dilalui oleh kendaraan. Model ini hanya bersifat mengingatkan sehingga diperlukan pesan yang menarik.

b) Signboard, media ini berupa papanpapan kecil dengan gambar petunjuk arah suatu lokasi tertentu. Media ini ditempatkan pada jalan yang menuju lokasi tersebut.

c) Umbul-umbul, media ini menampilkan gambar dengan warna yang mencolok sehingga memberikan suasana yang meriah

d) Sticker, merupakan iklan yang dipasang pada kendaraan-kendaraan umum seperti bus kota dan taksi. Umumnya, pemasangan iklan menggunakan stiker yang dipilih untuk kendaraan umum yang melalui jalur padat.
Copywriting harus bekerja dengan erat bersama dengan visualizer dan typographer (graphic designer) Karakteristik dasar copywriting adalah :

a. Copy iklan harus bersifat menjual, meskipun sebuah iklan mengingatkan saja

b. Rahasia keberhasilan iklan adalah pengulangan (repetition)

c. Pesan iklan harus memanfaatkan secara maksimal kata-kata dan menyampaikannya dengan segera

d. Setiap kata yang digunakan harus mudah dipahami dan familiar

e. Pergunakan kata-kata singkat dan palagraf pendek.

Minat beli dianalogikan sama dengan minat berkunjung. Menurut Schiffman dan Kanuk (2007:228) mendefinisikan minat beli merupakan suatu model sikap seseorang terhadap objek barang yang sangat cocok dalam mengukur sikap terhadap golongan produk, jasa, atau merek tertentu. Sedangkan menurut Howard yang dikutip dari Durianto dan Liana (2004:44) bahwa minat beli merupakan sesuatu yang berhubungan dengan rencana konsumen untuk membeli produk tertentu serta berapa banyak unit produk yang dibutuhkan pada periode tertentu. Menurut Kinnear dan Taylor yang dikutip oleh Tamrin (2003:142) bahwa minat beli merupakan bagian dari komponen perilaku konsumen dalam sikap mengkonsumsi, kecenderungan responden untuk bertindak sebelum keputusan membeli benar-benar dilaksanakan.

Pengertian dari tahap-tahap MODEL AIDA sebagai berikut:

1. Attention, Tahap ini merupakan tahap awal dalam menilai suatu produk atau jasa sesuai dengan kebutuhan calon pelanggan, selain itu calon pelanggan juga mempelajari produk atau jasa yang ditawarkan.

2. Interest, Dalam tahap ini calon pelanggan mulai tertarik untuk membeli produk atau jasa yang ditawarkan, setelah mendapatkan informasi yang lebih terperinci mengenai produk atau jasa yang ditawarkan.

3. Desire, Calon pelanggan mulai memikirkan serta berdiskusi mengenai produk atau jasa yang ditawarkan, karena hasrat dan keinginan untuk membeli mulai timbul. Dalam tahapan ini calon pelanggan sudah mulai berminat terhadap produk atau jasa yang ditawarkan. Tahap ini ditandai dengan munculnya minat yang kuat dari calon pelanggan untuk membeli dan mencoba produk atau jasa yang ditawarkan. 
4. Action, Pada tahap ini calon pelanggan telah mempunyai kemantapan yang tinggi untuk membeli atau menggunakan produk atau jasa yang ditawarkan.

\section{METODE PENELITIAN}

Penggunaan metode dilakukan agar memperoleh gambaran permasalahan sehingga tujuan penelitian tercapai dengan baik. jenis penelitian ini adalah penelitian deskriptif dan verifikatif. dengan metode deskriptif survey dan metode explanatory survey. Responden dalam penelitian ini pada wisatawan local dan nasional yang sedang berwisata di Kota Bandung baik wisata kota, belanja dan kuliner. teknik pengambilan sampel purposive sampling yang dilakukan selama bulan November 2016 pada hari Sabtu dan Minggu pada 100 responden.

\section{HASIL DAN PEMBAHASAN}

Berdasarkan hasil penelitian bahwa tujuan wisatatawan ke Kota Bandung, responden banyak yang memilik tujuan hanya wisata kota saja, hal ini menunjukan bahwa Kota Bandung benar-benar sebagai kota wisata, hanya dengan wisata kota saja mereka pengalaman dan kepuasanya sudah terpenuhi.
Selanjutnya adalah wisata belanja, hal ini membuktikan bahwa kota Bandung sebagai kota kreatif dalam menghasilkan produk baik pakaian ataupun lainnya seperti kuliner, sehingga dibuktikan wisatan yang dipilih selanjutnya adalah wisata kuliner, dengan beragam kuliner di Kota Bandung sebagai salah satu tiga tujuan tertinggi dalam memilih wisata ke Kota Bandung, sedangkan untuk wisata alam lebih rendah, dan wisata edukasi benear-benar sangat rendah. Hal ini membuktikan bahwa tidak ada peminatan dari wisatawan dalam mengunjungi wisata museum di Kota Bandung. Padahal Kota Bandung memiliki 6 museum yang sangat menarik termasuk museum Asia Afrika yang lokasinya tepat berada di tengah kota wisata di daerah Alun-Alun, tetapi responden tetap saja mereka tidak minat untuk mengunjungi ke dalam museum Asia Afrikanya. Mereka hanya lebih memilih dan tertarik berada diluar museum Asia Afrika hanya dengan menikmati diluar saja dan berfoto di area museum Asia Afrika. Hal ini membuktikan bahwa wisata edukasi museum benarbenar kurang diminati oleh wisatawan Kota Bandung. Berikut data hasil penelitian.

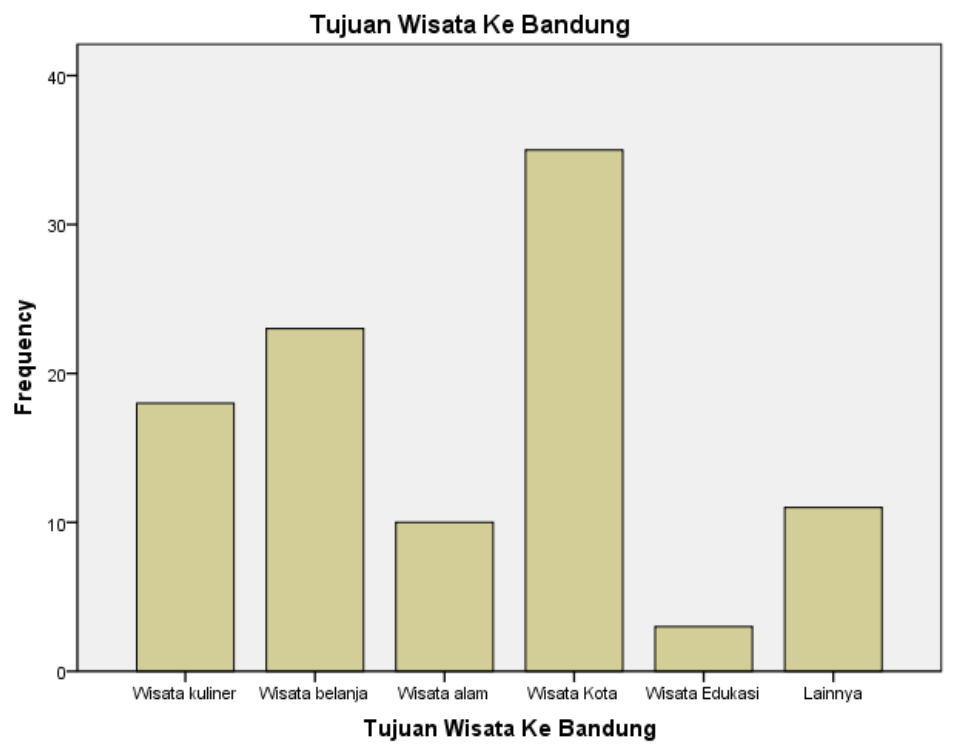

Berdasarkan table tersebut bahwa tujua wisatawan datang ke Bandung yang palinh tinggi adalah wisata kota, dimana saat ini banyak sekali dilakukan pembangunan di Kota Bandung seperti Alun-Alun Bandung yang di desain seperti arena bermain serta disediakannya perlatan olah raga, Asia Afrika sebagai pembangunan sejarah serta dijadikan sebagai sarana wisata kota yang didukung oleh banyaknya boneka dan tokoh anak untuk difoto dengan para wisatwan, selanjutnya banyaknya pembangunan taman-taman tematik seperti taman lansia dengan maksud taman tersebut diperuntukan untuk kegiatan olah raga para orang tua, taman robot yang disediakan untuk anakanak, teman vanda, dan banyak lagi. Hal ini ternyata sebagai daya tarik para wisatawan untuk datang ke Kota Bandung. Selanjutnya adalah wisata belanja dan 
kuliner, bahwa kota Bandung sebagai kota Paris Van Java membuat menjadikan sebagai pusat pembelanjaan dengan trend pakaian yang kekinian, ditambahkan dengan banyaknya café dan resto membuat daya tarik Kota Bandung memvariasi makanan yang ada serta enovatif dan kreatif serat unik-unik membuat daya tarik kuliner semakin tinggi. Sedangkan wisata alam saat ini sedikit diminati, begitu pula dengan wisata edukasi museum sangat rendah. Dengan demikian hal ini seharusnya dijadikan landasan bagi pemerintah daerah Kota Bandung dalam meningkatkan minat wisatawan mengunjungi museum.

Dengan demikian untuk menarik minat wisatawan mengunjungi museum di Kota Bandung salah satunya adalah dengan pemasangan billboard dengan desain yang menarik dan sesuai dengan trend saat ini, yaitu

\section{StrategiC}

peneliti melakukan kerjasama dengan graphic desaigner dengan hasil desaign kartun museum dengan sasarannya adalah wisatawan local, nasional dan internasional yang berkunjung ke Kota Bandung. Diharapkan media promosi ini dapat menarik minat para wisatawan Kota Bandung. Berikut hasil desain yang akan dijadikan sebagai media promosi melalui billboard.

Dengan demikian pemasangan billboard tersebut sebagaiknya ditempatkan di tempat-tempat wisata Kota seperti di daerah Alun-Alun Bandung, Asia Afrika, dan di taman-taman tematik yang sering dikunjungi oleh para wisatawan.

Berikut desain kartun dalam meningkatkan minat kunjungan museum.

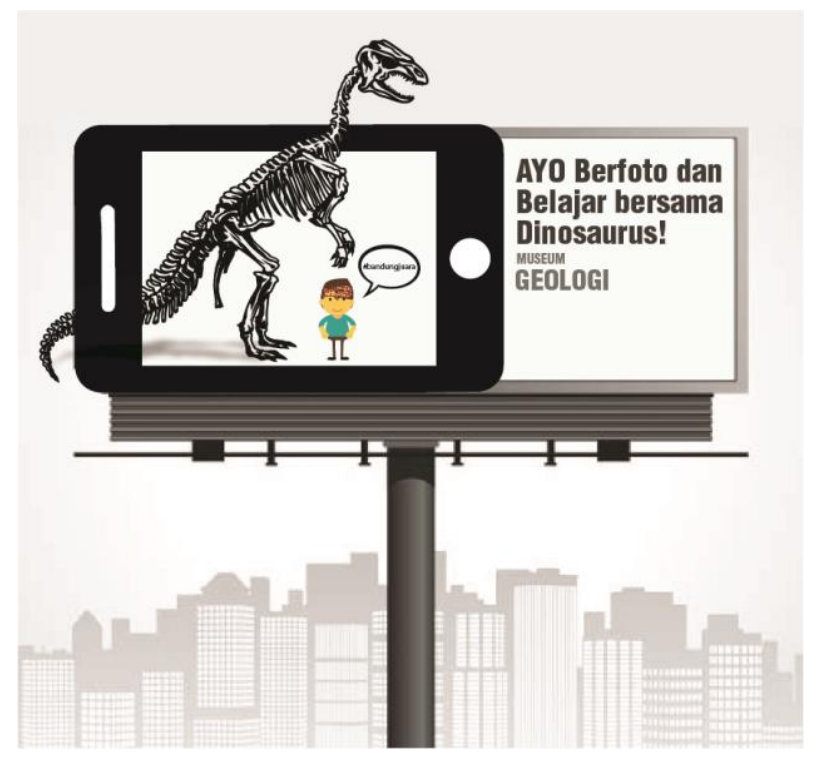

Gambar di atas adalah desain billboard untuk menarik wisatawan dalam mengunjungi museum Geologi, dengan konsep kartun dan icon dinosaurus diharapkan akan menarik minat wisatawan serta dengan tagline Ayo berfoto dan belajar bersama Dinosaurus diharapkan membuat penasaran para wisatawan meskipun pada awalnya wisatawan tidak memiliki niat untuk wiisata ke museum, diharapkan adanya iklan ini melalui billboard dapat menciptakan minat wisatawan 


\section{StrategiC}

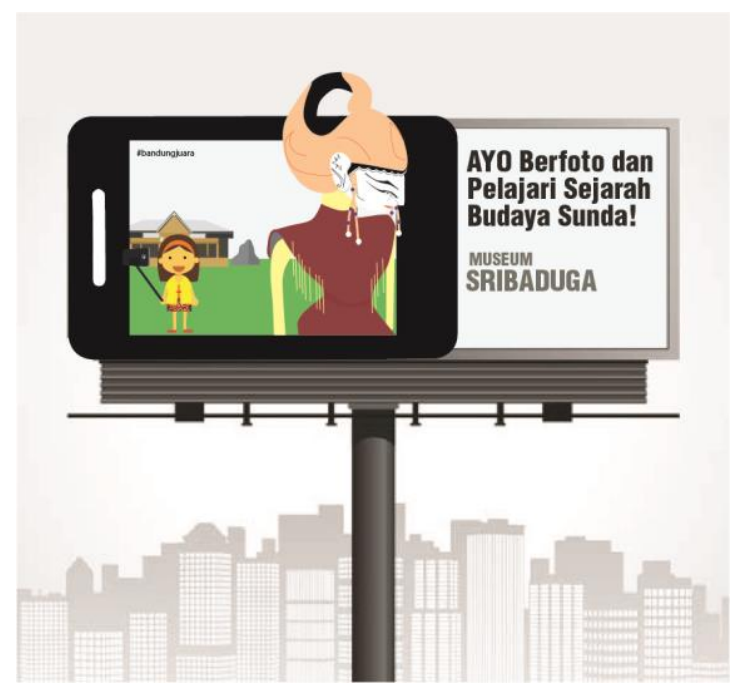

Gambar di atas sebagai bentuk promosi Museum Sribaduga dengan icon wayang golek sebagai khas sunda, menyampaikan pesan belajar sejarah dan budaya sunda. Dengan konsep yang sama dengan visi museum, yaitu dengan berkunjungnya ke museum Sribaduga maka wisatawan akan belajar sejarah dan budaya Sunda salah satunya peninggalan kerajaan Padjajaran dan Madjapahit.

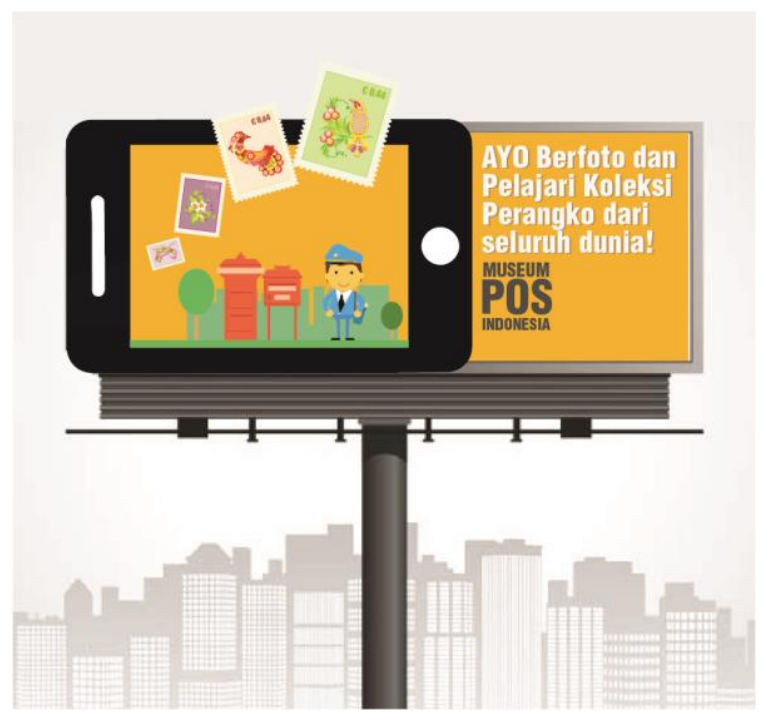

Gambar promosi museum kantor pos memperkenalkan sejarah pos di Indonesia yang mencakup koleksi perangko dari zaman dahulu hingga saat ini termasuk di berbagai negara, selain itu dengan benda-benda yang berkaitan dengan pos. 


\section{StrategiC}

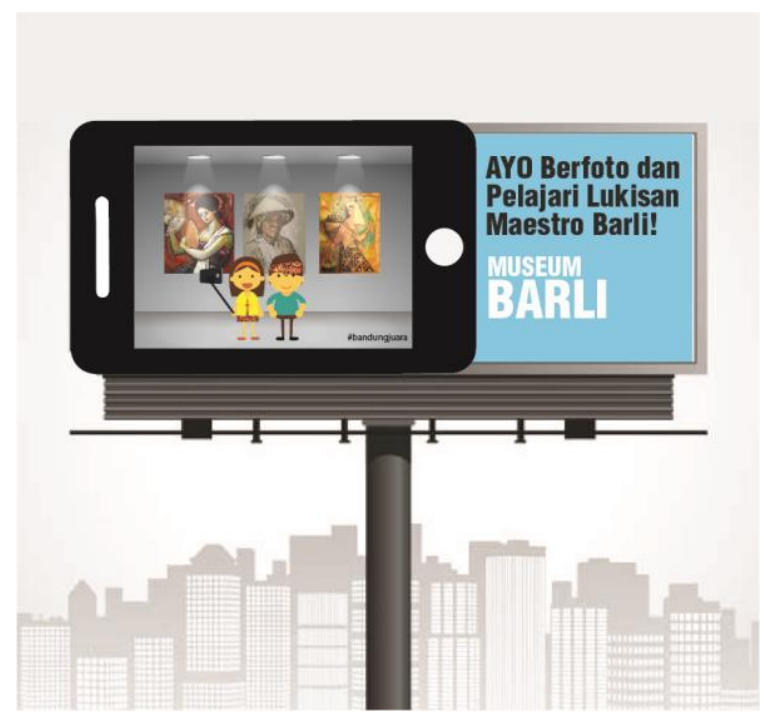

Gambar diatas adalah promosi museum Barli, desain tersebut memperlihatkan wisatawan sedang berfoto di depan koleksi lukisan di Barli.

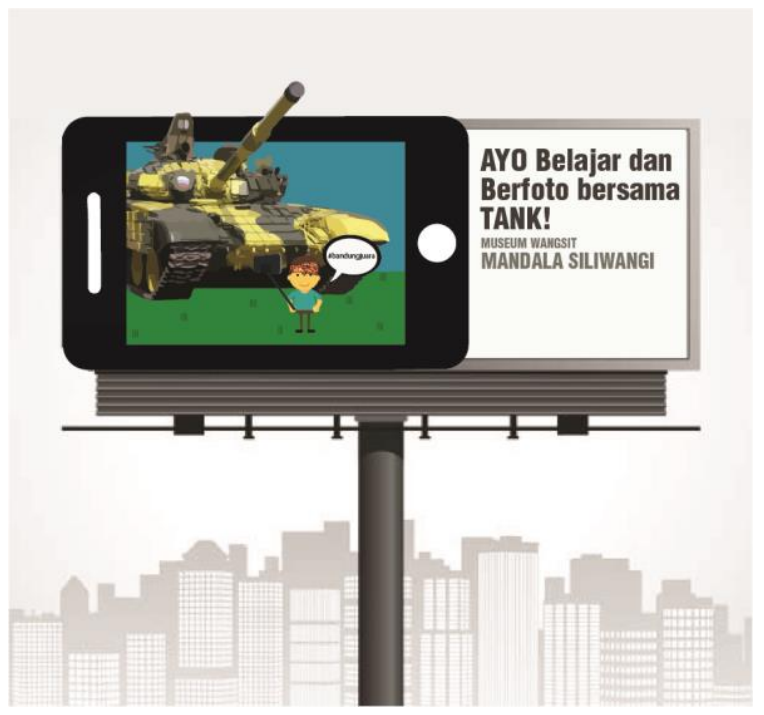

Gambar desain diatas menunjukan museum Mandala Wangsit Siliwangi yang terlihat adanya transportasi tank. Tank ini sebagai symbol peperangan yang menunjukan museum mandala wangsit siliwangi adalah museum perlengkapan angakatan darat Indonesia 


\section{StrategiC}

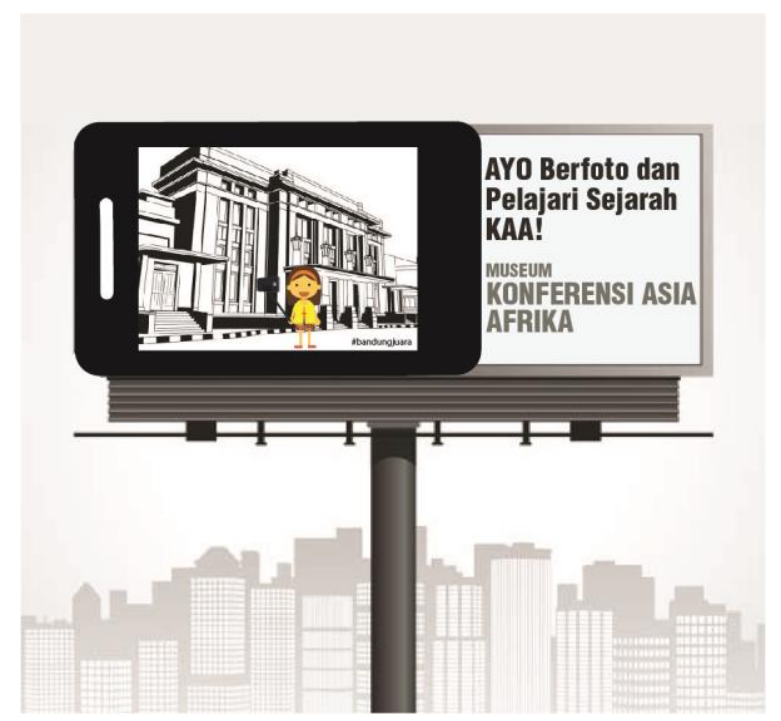

Desain gambar diatas terlihat seorang wisatawan yang sedang berfoto didepan gedung Asia Afrika, dima gedung ini sebagai gedung sejarah Konferensi Asia Afrika, yang sampai saat ini banyak peminat untuk berfoto di depan gedung tersebut, hanya saja wisatawan jarang memasuki museumnya, dengan adanya iklan ini diharapkan minat wisatawan untuk mempelajari sejarah KA
Berdasarkan hasil penelitian yang diperoleh mengenai survey pada 6 desain kartun museum tersebut dengan pengolahan data pada kuesioner yang disebar adalah sebagai berikut.

Bahwa Variabel promosi melalui media billboard dengan desain kartun sebagai variabel $\mathrm{X}$ dan minat wisata sebagai variabel Y, sebagai berikut:

\begin{tabular}{|ll|r|r|}
\hline \multicolumn{2}{|c|}{ Correlations } & \multicolumn{1}{|c|}{$\begin{array}{c}\text { minat } \\
\text { berkunjung }\end{array}$} & Iklan Bilboard \\
\hline Pearson Correlation & minat berkunjung & 1.000 & .373 \\
& Iklan Bilboard & .373 & 1.000 \\
\hline Sig. (1-tailed) & minat berkunjung & .000 & .000 \\
& Iklan Bilboard & 100 & 100 \\
\hline $\mathrm{N}$ & minat berkunjung & 100 & 100 \\
\hline & Iklan Bilboard & & \\
\hline
\end{tabular}

Berdasarkan data tersebut tingkat keerata hubungan promosi melalui billboard dengan desain kartun yang dirancang dengan variable meningkatkan minat wisatawan dalam berkunjung menghasilkan hubungan yang sangat erat dan positif, dengan tingkat signifikan sebesar 0,000. Hal ini menunjukan desain iklan yang telah dirancan oleh peneliti dapat meningkatkan minat wisatawan.

Model Summary ${ }^{b}$

\begin{tabular}{|l|l|l|l|l|l|}
\hline Model & $\mathrm{R}$ & R Square & $\begin{array}{l}\text { Adjusted R } \\
\text { Square }\end{array}$ & $\begin{array}{l}\text { Std. Error of the } \\
\text { Estimate }\end{array}$ & Durbin-Watson \\
\hline dimension0 & 1 & $.373 \mathrm{a}$ & .139 & .130 & 2.373 \\
\hline
\end{tabular}

a. Predictors: (Constant), Iklan Bilboard

b. Dependent Variable: minat berkunjung 
Model summary ini menunjukkan R Square sebesar 0,139. R Square ini disebut sebagai koefisien determinasi, dengan nilai $\mathrm{R}$ sebesar 0,373 Hal ini menunjukan secara statistic $37 \%$ minat wisatawan Kota Bandung dipengaruhi sebanyak 37\% ketika mereka telah melihat desain billboard yang telah dirancang oleh peneliti. Sehingga para wisatawan yang selama ini tidak niat untuk berkunjung ke museum kota Bandung dan dengan melihat iklan billboard tersebut menjadi minat berkunjung ke museum. Angka ini merupakan angka yang sangat tinggi, berarti dengan desain billboard yang telah dirancang ini dapat meningkatkan minat wisatawan sebanyak $37 \%$ untuk mengunjungi museum Kota Bandung

\begin{tabular}{|ll|r|r|r|r|r|}
\hline Model & & Sum of Squares & df & Mean Square & \multicolumn{1}{c|}{ F } & Sig. \\
\hline 1 & Regression & 89.156 & 1 & 89.156 & 15.828 & $.000^{\text {a }}$ \\
& Residual & 552.004 & 98 & 5.633 & & \\
& Total & 641.160 & 99 & & & \\
\hline
\end{tabular}

a. Predictors: (Constant), Iklan Bilboard

b. Dependent Variable: minat berkunjung

Tabel diatas menunjukan bahwa F Test sebesar 15.828 dengan tingkat signifikan sebesar 0,000. Hal ini berarti desain billboard yang telah dirancang oleh peneliti dapat meningkatkan dan mempengaruhi jumlah atau tingkat minat wisatawan untuk mengunjungi museum.

Coefficients $^{\mathrm{a}}$

\begin{tabular}{|c|c|c|c|c|c|c|c|c|}
\hline \multirow{2}{*}{\multicolumn{2}{|c|}{ Model }} & \multicolumn{2}{|c|}{$\begin{array}{l}\text { Unstandardized } \\
\text { Coefficients }\end{array}$} & \multirow{2}{*}{$\begin{array}{c}\begin{array}{c}\text { Standardiz } \\
\text { ed } \\
\text { Coefficient } \\
\text { s }\end{array} \\
\text { Beta }\end{array}$} & \multirow[b]{2}{*}{$\mathrm{T}$} & \multirow[b]{2}{*}{ Sig. } & \multicolumn{2}{|c|}{ Collinearity Statistics } \\
\hline & & $\mathrm{B}$ & Std. Error & & & & Tolerance & VIF \\
\hline 1 & (Constant) & 3.449 & 2.217 & & 1.556 & .123 & & \\
\hline & Iklan Bilboard & .549 & .138 & .373 & 3.978 & .000 & 1.000 & 1.000 \\
\hline
\end{tabular}

a. Dependent Variable: minat berkunjung

Berdasarkan Tabel tersebut menunjukan bahwa koefisien regresi 0,549 dan bertanda positif (+), hal ini menunjukan bahwa jika pengelola museum atau pemerintah Kota Bandung menambahkan promosi 1 kali melalui billboard dengan desain mengikuti trend saat ini, atau minimalnya dengan

\section{KESIMPULAN DAN SARAN}

Berdasarkan hasil penelitian yang sudah dilakukan maka dapat disimpulkan bahwa:

1. Urutan tujuan wisatawan mengunjungi Kota Bandung terdiri dari wisata kota, wisata belanja, wisata kuliner, wisata alam,dan terakhir adalah wisata museum

2. Billboard - billboard yang ada di Kota Bandung tidak ada yang memberikan petunjuk untuk berwisata ke Museum. Sehingga dengan adanya penelitian dan design kartun dapat meningkatkan desain kartun maka dapat meningkatkan jumlah pengunjung sebesar $54 \%$.

Dengan demikian adanya konsep keterbaruan ini dalam media promosi museum di Kota Bandung dapat meningkatkan minat wisatawan Kota Bandung dalam mengunjungi wisata museum.

minat wisatawan untuk berkunjung ke museummuseum yang ada di Kota Bandung.

3. Semua museum di Kota Bandung belum ada yang melakukan promosi dengan menggunakan billboard dengan desain kartun seperti trend saat ini 


\section{StrategiC}

\section{DAFTAR PUSTAKA}

Abdullah, Thamrin. (2003). Manajemen Produksi dan Industri Kecil. Jakarta : Pusat Penerbit Universitas Terbuka

Dharmasita (2008) Manajemen Pemasaran Modern. Edisi Kedua.Yogyakarta: Liberty

Durianto,Darmadi, Cicilia Liana, (2004). Analisis Efektifitas Iklan Televisi Softener Soft \& Fresh di Jakarta dan Sekitarnya dengan Menggunakan Consumer Decision Model, Vol.11, No. 1.

Freddy Rangkuti,. (2010). Strategi Promosi yang Kreatif dan Analisis Kasus Integrated Marketing Communication. Jakarta : PT. Gramedia Pustaka Utama

Fandy Tjiptono (2005). Pemasaran Jasa, Edisi Pertama, Bayu Media Publishing, Malang

Masri Singarimbun (2006). Metode Penelitian Survei. Jakarta : Pustaka LP3ES

Kasali, Rhenald. (2007). Membidik Pasar Indonesia Segmentasi Targeting Positioning. Jakarta : PT Gramedia Pustaka Utama

Simamora, Bilson. (2004). Riset Pemasaran. Cetakan Pertama. Jakarta; PT. Gramedia Pustaka Utama.
Suharsimi Arikunto (2005). Prosedur Penelitian, Suatu Pendekatan Praktek. Jakarta. Rineka Cipta

Sugiyono. 2010. Metode Penelitian Bisnis. Bandung: Alfabeta.

Sutisna (2002), Perilaku Konsumen, Bandung. Rosda Karya

Sugiyono. (2013). Metode Penelitian Kualitatif. Bandung: Alfabeta

Sugiyono. (2005). Metode Penelitian Bisnis.

Bandung: Alfabeta

\section{Sumber Lain}

Rencana Strategis Disbudpar Kabupaten/Kota Bandung, 2013

http: padmanaba.or.id/6/4/2006

http://travel.kompas.com/ Selasa, 28 Januari 2014 | 14:41 WIB

(http://bandung.merdeka.com/)

http://regional.kompas.com

\section{RIWAYAT PENULIS}

Ani Solihat, S.Pd., SST., MM adalah dosen Manajemen dan Entrepreneur AMIK BSI Bandung dengan alamat Jalan Sekolah Internasional No $1-6$ Bandung. No Hp : 083820027300 